\title{
PHYSICOCHEMICAL CHARACTERIZATION OF AVOCADO OIL BY-PRODUCTS
}

\author{
Juana Edelia Vidales-Paz1, 2, Lorena De Medina-Salas1, 3, Pedro Ulises Bautista-Rosales², 4, Ma. del Rosario Pérez- \\ Saucedo2, 4, Paloma Patricia Casas-Junco²

\begin{abstract}
1 Universidad Internacional Iberoamericana. Calle 15 No. 36, entre 10 y 12, Imi, III, 24560, Campeche, Camp., México.
2 Unidad de Tecnología de Alimentos, Universidad Autónoma de Nayarit. Ciudad de la Cultura S/N. Col. Centro. C. P. 63000. Tepic, Nayarit, México.

3 Universidad Veracruzana. Facultad de Ciencias Químicas. Circuito Gonzalo Aguirre Beltrán s/n. Zona Universitaria C.P. 91040, Xalapa, Veracruz, Mexico. Phone number: +52-2288421758

4 Programa de Doctorado en Ciencias Biológico Agropecuarias, Universidad Autónoma de Nayarit. Km. 9, Carretera Tepic-Compostela.
\end{abstract} C.P. 63780. Xalisco, Nayarit, México."

Email: Idemedina@uv.mx

\section{ABSTRACT}

Considering that currently the oil agribusiness has shown interest only in the bioactives present in the avocado seed and peel, the objective of the present work consisted in physically characterizing the by-products obtained from the extraction of the Persea americana "Hass" avocado oil through the application of High Intensity Ultrasound (HIU) and Cold Extraction (CE) because both technologies are environmentally friendly and also produce products with better nutritional and organoleptic characteristics. The results obtained in the by-products (aqueous phase as in the spent pulp) showed the presence of unsaturated fatty acids and free fatty acids from the hydrolysis of their triacylglycerides, observing that the highest value of the iodine number in both the spent pulp and in the aqueous phase it required the highest power $562.5 \mathrm{~W}$ and maximum sonication time (15 minutes). In relation to the acid number, the highest value in the aqueous phase was presented at power $375 \mathrm{~W}$ and a time of 15 minutes, while in the spent paste, unlike the above, this was obtained at the lowest power $187.5 \mathrm{~W}$ and shorter time (5 minutes). Therefore, it is probable that to obtain bioactive compounds, the higher the power generated by the longitudinal mechanical wave and the sound, they cause the avocado cell wall to fragment, generating a greater output of fatty acids and possibly the formation of lipid emulsions.
\end{abstract}

Keywords: bioactive compounds, avocado oil extraction, spent paste, aqueous phase, highintensity ultrasound. 


\section{Introduction}

The avocado is considered native to southern Mexico and Central America [1]. Mexico ranks first in world production, contributing $50 \%$ ( 1 million 100 thousand tons of fruit) of the production, which is exported to more than 30 countries [2].

The avocado fruit is consumed mainly fresh and appreciated for its high nutritional content [1]. This is because mainly of its content of fatty acids monounsaturated, polyunsaturated, and substantial amounts of phytosterols, vitamins, and minerals. This is why it is considered a functional food with great health benefits [3]. Besides, Chin [4] mentions that avocado fruit contains more than 20 essential nutrients, some of them related to the inhibition of cancer tumors [4], as well as high amounts of minerals such as magnesium, potassium, and phosphorous [3], which is why, innovative way, New Zealand began extracting its oil in the late of 1990s [5].

Currently, avocado fruit is industrialized and used as raw material for oil production through relatively severe methods such as high temperatures and extraction by organic solvents, usually accompanied by standard refining measures blenching and deodorization [6]. However, traditional techniques show low extraction yields, prolonged application times, and affect the oil quality due to the presence of organic solvents traces. The extraction efficiency is reduced mainly by polysaccharides such as hemicellulose, starch, and pectin present within the cell wall [7]. Therefore, it is necessary to use new extraction and ecological methods to recover biomolecules [6]. Due to the above, alternative methods are proposed for avocado oil extraction, such as supercritical fluids, microwaves, and enzymatic extraction $[8,9]$.

Therefore, due to the demand for green technologies, high-intensity ultrasound (HIU), centrifugation, and cold pressing are currently being used for avocado oil extraction. All of them are considered clean and environmentally friendly technologies. Those technologies can be applied alone or in combination, as with enzymatic pre-treatments or pulp drying [10].

The HIU technique is based on acoustic energy; therefore, a non-ionizing, noninvasive, and non-polluting form that, due to its operational characteristics, is currently considered an emerging method with great control potential to improve and accelerate the processes without damaging food quality [11]. It is also regarded as profitable because it reduces the extraction time and energy consumption derived from the physicochemical effects of the cavitation phenomenon induced by ultrasonic waves [12]. Its energy is generated by a longitudinal mechanical wave above the audible limit for humans, produced by the vibration of an elastic body-piezoelectric crystal [13]. Aspects of caring for the environment for vegetable oil extraction have been overlooked for many years [14]. However, during industrialization processes, such as avocado oil extraction, many by- 
products are generated with limited commercialization or use, so very few byproducts are exploited in the industry $[8$, 15].

For all the above, it is important to implement new transformation processes in the agro-industry where, together with clean technologies, these allow to maintain their products with better organoleptic characteristics. Likewise, it is necessary that environmentally, there is a vision of characterizing the by-products generated to propose possible uses, giving them added value and thus contributing to this basic perspective of the circular economy. Based on the above, the objective of the present work was to evaluate the effect of ultrasound coupled with cold extraction, the power, and sonication time on the by-products of avocado oil extraction.

\section{Material and methods}

\section{Plant material}

Avocado fruits (Persea americana) in physiological maturity were collected from an orchard in Xalisco, Nayarit, (21 26 ' 39 " $\mathrm{N}-104^{\circ} 54^{\prime} 06$ " W; 984 masl) transporting them to the Food Technology Laboratory, from the Universidad Autónoma de Nayarit. The avocado fruits were handled under safe conditions, washing with soap and water and disinfecting with sodium hypochlorite in $2 \%$ solution for 3 minutes and subsequent rinsing.

\section{Avocado paste}

The avocado fruit was peeled and the seed removed. The avocado pulp was homogenized for 1 minute in a $\mathrm{Hp}$ International Li-12 industrial blender. The avocado paste obtained was packed in bags of around $1 \mathrm{~kg}$ and stored at $-18^{\circ} \mathrm{C}$ until later use.

\section{Oil extraction and production of by- products}

The experimental design for the extraction of avocado oil and its by-products (spent paste and aqueous phase) was of the factorial type $(3 \times 3)$, whose variables included the application of three powers $187.5 \mathrm{~W}, 375 \mathrm{~W}$, and $562.5 \mathrm{~W}$ and three times $(5,10$ and 15 minutes) of sonication.

The high-intensity ultrasound conditions were based on modifications to those described by Clodoveo et al. [16] and cold extraction, as mentioned by Costagli and Betti [17] with modifications.

\section{By-products of avocado oil extraction}

For the extraction of by-products, $200 \mathrm{~g}$ of avocado paste were taken and placed in a beaker. Using a Cole Parmer Instruments Model CPX750 ultrasonic equipment, a titanium ultrasonic probe with a diameter of $2.54 \mathrm{~cm}$ was introduced, and the samples were treated under the times and powers mentioned above.

From the sonicated paste, $25 \mathrm{~g}$ were taken and placed in Falcón tubes with a capacity of $50 \mathrm{~mL}$. The samples were centrifuged at $10,000 \mathrm{rpm}(1,667 \mathrm{xg})$ for 10 minutes at $40{ }^{\circ} \mathrm{C}$, in Eppendorf brand equipment, model 5804R, separating the oil, the spent paste, and the aqueous phase, recovering the by-products of the oil extraction (spent paste and aqueous 
phase) for its physicochemical characterization.

\section{Physicochemical characterization}

Physicochemical parameters were determined for both the aqueous phase and the spent paste based on Official Methods and Recommended Practices of the AOCS.

\section{lodine index ( $\mathrm{YI})$}

The iodine index was evaluated following the Wijs technique [18]. The YI was expressed as $\mathrm{g}$ of iodine absorbed per 100 $g$ of oil. The iodine index indicates the unsaturation degree of the oils presents in samples.

\section{Acidity index (Al)}

The acidity index was determined using the volumentric method and the results were expressed as a percentage of oleic acid [18].

\section{Results and discussion}

Table 1 shows the physicochemical analysis results on both the aqueous phase and the spent paste by applying highintensity ultrasound and cold extraction. The preponderant factors were time ( $p$ $<0.05$ ) and power $(p<0.05)$.

The iodine index values in the aqueous phase were found from $18.34 \pm 4.73 \mathrm{cgl}_{2} / \mathrm{g}$ to $42.81 \pm 3.57 \mathrm{cgl}_{2} / \mathrm{g}$, the highest values being found in power $562.5 \mathrm{~W}$ and time of
15 minutes and the lowest in power 187.5 $W$ and time of 5 minutes. On the other hand, the iodine index in the spent paste ranged from $19.36 \pm 3.31 \mathrm{cgl}_{2} / \mathrm{g}$ to $32.95 \pm$ $14.93 \mathrm{cgl}_{2} / \mathrm{g}$. The highest value was found at 5 minutes and the power $562.5 \mathrm{~W}$, while the lowest value was found at 5 minutes and power $187.5 \mathrm{~W}$ (Table 1). The above indicates that it is possible to obtain a greater amount of unsaturated fatty acids in both by-products due to the energy generated by the longitudinal mechanical wave and the sound when the ultrasonic waves are applied with the power $562.5 \mathrm{~W}$. This may be because the ultrasound caused the avocado cell wall fragmentation, generating a greater output of unsaturated fatty acids [12].

The results obtained in the aqueous phase reflect the considerable presence of unsaturated fatty acids, so they are probably represented by membrane lipids such as phospholipids. In this aqueous byproduct, glycolipids because both have a hydrophilic fraction in their chemical structure (soluble in water) and unsaturated fatty acids[14]. It has also been reported phosphatidylcholine, lyso phosphatidyl choline, phosphatidyl ethanolamine, phosphatidyl inositol, phosphatidic acid, and phosphatidyl glycerol in avocado paste [15]. 
Table 1. Physicochemical analysis of byproducts of avocado oil extraction.

\begin{tabular}{|c|c|c|c|c|}
\hline \multirow[t]{2}{*}{ Physicopechemical parameter } & \multirow{2}{*}{$\begin{array}{l}\text { Sonication } \\
\text { time (min) }\end{array}$} & \multicolumn{3}{|c|}{ Power } \\
\hline & & $187.5 \mathrm{~W}$ & $375 \mathrm{~W}$ & $562.5 \mathrm{~W}$ \\
\hline \multirow{3}{*}{$\begin{array}{c}\text { lodine index } \\
\text { aqueous phase } \\
\left(\mathrm{cgl}_{2} / \mathrm{g}\right)\end{array}$} & 5 & $18.34 \pm 4.73$ & $25.48 \pm 1.72$ & $29.68 \pm 1.91$ \\
\hline & 10 & $21.64 \pm 1.99$ & $28.93 \pm 15.83$ & $37.75 \pm 1.99$ \\
\hline & 15 & $31.40 \pm 7.61$ & $29.72 \pm 2$ & $42.81 \pm 3.57$ \\
\hline \multirow{3}{*}{$\begin{array}{c}\text { lodine index } \\
\text { Spent paste } \\
\left(\mathrm{cgl}_{2} / \mathrm{g}\right)\end{array}$} & 5 & $19.36 \pm 3.31$ & $29.09 \pm 12.23$ & $32.95 \pm 14.93$ \\
\hline & 10 & $27.66 \pm 18.34$ & $26.36 \pm 15.22$ & $30.03 \pm 9.79$ \\
\hline & 15 & $22.23 \pm 2.35$ & $30 \pm 9.48$ & $21.10 \pm 9.97$ \\
\hline \multirow{3}{*}{$\begin{array}{c}\text { Acidity index } \\
\text { Aqueous phase } \\
\text { (\% oleic acid) }\end{array}$} & 5 & $1.72 \pm 0.10$ & $1.91 \pm 0.09$ & $2.0 \pm 0.01$ \\
\hline & 10 & $2.0 \pm 0$ & $1.78 \pm 0.25$ & $1.90 \pm 0.28$ \\
\hline & 15 & $1.83 \pm 0.01$ & $2.14 \pm 0.31$ & $1.44 \pm 0.11$ \\
\hline \multirow{3}{*}{$\begin{array}{l}\text { Acidity index } \\
\text { Spent paste } \\
\text { (\% Oleic acid) }\end{array}$} & 5 & $2.34 \pm 0.15$ & $1.94 \pm 0.11$ & $2.17 \pm 0.08$ \\
\hline & 10 & $2.31 \pm 0.17$ & $1.95 \pm 0.10$ & $2.01 \pm 0.01$ \\
\hline & 15 & $2.31 \pm 0.17$ & $2.25 \pm 0.22$ & $1.86 \pm 0.05$ \\
\hline
\end{tabular}

Regarding the spent pulp and the aqueous phase, both required power of 562.5 W to obtain a greater amount of unsaturated fatty acids; however, the spent paste also required the maximum sonication time (15 minutes), this caused effects physical causes, causing rupture of the cell wall, reduction of the size of the particles and accelerated emptying of their membranes [19], so it is likely that the rapid release of fatty acids remained in the form of lipid emulsions, probably consisting of carbohydrates and proteins due to the fact that at this maximum power and longer exposure time, the mass transfer mechanism is further accelerated, which is attributed to the pressure of the propagated waves [20], based on the fact that there are studies that report that the pulp of avocado has 5\% carbohydrates and $2 \%$ protein [21].

On the other hand, and considering that CODEX 210-1999 reports an iodine value of
82 to $90 \mathrm{cgl}_{2}$ / g as normal in avocado oil. The values found in the aqueous phase and the spent paste indicate its probable source of unsaturated fatty acids for use in the food, cosmetic or pharmaceutical industry to formulate their products.

The acidity index in the aqueous phase presented values between $1.44 \pm 0.11$ and $2.14 \pm 0.3 \%$ of fatty acids, being the highest in power $375 \mathrm{~W}$ and time of 15 minutes, the lowest values were obtained in power $562.5 \mathrm{~W}$ with sonication time of 15 minutes; therefore, there were no significant differences between time and power. Concerning the depleted paste, the acidity index values were from $1.86 \pm 0.05$ to $2.34 \pm 0.15$, being the highest in power 187.5 $\mathrm{W}$ and time of 5 minutes, while the lowest values were in power $562.5 \mathrm{~W}$ with a sonication time of 15 minutes (Table 1).

The results obtained in the aqueous phase indicate that at a power of $375 \mathrm{~W}$ and with 
an ultrasonic exposure of 15 minutes, the triacylglycerides present were hydrolyzed, leaving the fatty acids free in this matrix, while in the spent paste, lower power and exposure time were required: $187.5 \mathrm{~W}$ and 5 minutes respectively. Therefore, due to the hydrophilic nature of the aqueous phase, it could require greater power to break the ester bonds that bind fatty acids to glycerol [14] due to its low polarity [22], and they are likely to be found in emulsion form.

On the other hand, and based on what was observed in the avocado paste, it is probable that the acid number of the spent paste is represented in the first instance by oleic acid, followed by linoleic and palmitoleic [23].

CODEX 210-1999 reports as normal values of acidity index in avocado oil a maximum of $0.1 \%$ of free fatty acids (oleic acid), values lower than those found in this study. Free fatty acids, both in the aqueous phase and in the spent paste, could be susceptible to exhibiting considerable levels of hydrolytic rancidity in their contained triacylglycerides in presence of high levels of oxygen, which would limit their use for cosmetology, food or cosmetic purposes. Both in the aqueous phase and the spent paste generated during the extraction of avocado oil through highintensity ultrasound and cold extraction and until now not analyzed, it was possible to characterize the presence of bioactive compounds in these by-products, which makes them probably useful for the food, cosmetic or pharmaceutical industry.
It is important that at an industrial level, the production cycles are closed to optimize their processes, take advantage of the byproducts formed, and avoid generating waste that pollutes natural resources. Also, it is vital that they replace the use of obsolete or unprofitable technologies with those that are friendly to the environment, such as high-intensity ultrasound and cold extraction, which also allow obtaining products of better organoleptic quality in less time and with less energy consumption, whose applications at an industrial level are versatile and quite useful and innovative within food processes.

\section{References}

1. Araujo R, Rodríguez R, Ruiz A, Pintado E, Aguilar $\mathbf{N}$ (2018) Avocado by-

en Colombia, obtenido por fluidos supercríticos y métodos convencionales products: Nutritional and functional properties. Trends in Food Science \& Technology 80: 51-60.

2. SENASICA. Servicio Nacional de Sanidad, Inocuidad y Calidad Agroalimentaria (2020) Plagas reglamentadas del aguacatero Gobierno de México Recuperado de https://www.gob.mx/senasica/documento s/plagas-reglamentadas-del-aguacatero110847 el 3 de abril del 2020.

3. Chin T (2019) Virgin avocado oil: An emerging source of functional fruit oil. Journal of Functional Foods 54: 381-392.

4. Restrepo D, Londoño L, González Á, Benavides P, Cardona S (2012) Comparación del aceite de aguacate variedad Hass cultivado: una perspectiva 
desde la calidad. Revista Lasallista de Investigación 9: 151-161.

5. Vargas R, Gutarra S, Delgado S, Cortés A, Elías P (2020) Ácidos grasos y criterios de calidad del aceite de palta obtenido mediante tres sistemas de extracción libres de solvente. Agroindustrial Sciences 10: 7177.

6. Yepes D, Sánchez L, Márquez C (2017) Extracción termomecánica y caracterización fisicoquímica del aceite de aguacate (Persea americana Mill. cv. Hass). Informador Técnico Colombia 81: 75-85.

7. Nadar S, Rao P, Rathod V (2018) Enzyme assisted extraction of biomolecules as an approach to novel extraction technology. A review. Food Res. Int. 108: 309-33.

8. Corona J, Martínez N, Ruiz E, Carranza C (2016) Extracción asistida por ultrasonido de compuestos fenólicos de semillas de chia (Salvia hispanica L.) y su actividad antioxidante. Agrociencia, 50: 403-412.

9. Vásquez $O$, Hincapié $L$, Cardona $M$, Jaramillo D, Vélez A (2017) Formulación de una colada empleando harina de sacha inchi (Plukenetia volubilis L.) proveniente del proceso de obtención de aceite. Perspectivas en Nutrición Humana 19: 167-179.

10.Serpa A, Echeverri A, Lezcano M, Vélez L, Ríos A, Hincapié G (2014) Extracción de aceite de aguacate variedad "Hass" (Persea americana Mill) liofilizado por prensado en frio. Revista Investigaciones Aplicadas, 8:1 18-128.

11. Alarcón A, Carrillo L, Reyes R, Huerta $M$, García I (2019) Ultrasound and meat quality. A Review Ultrasonics Sonochemistry 55: 369-382.
12. Alzorqi A, Singh A, Manickam S, Haidar F, Al-Qrimli H (2016) Optimization of ultrasound assisted extraction (UAE) of $\beta$-Dglucan polysaccharides from Ganoderma lucidum for prospective scale-up. Resource Efficient Technologies 3: 46-54.

13. Hernández $M$, Morales J, Valenzuela $R$, Morales G, Valenzuela A (2016) Beneficios de los ácidos grasos poliinsaturados de cadena larga n-3 en la enfermedad por hígado graso no alcohólico. Revista Chilena de Nutrición 43: 196-205.

14. Ros E, Miranda J, Pico J, Rubio C, Babio M y Sala V. (2015) Consenso sobre las grasas y aceites en la alimentación de la población española adulta; postura de la Federación Española de Sociedades de Alimentación, Nutrición y Dietética (FESNAD). Nutrición Hospitalaria, 32: 435-477.

15. Bosmuler L, Aparecida H, Meira J, da Silva V, Scheer A (2017) Use of avocado phospholipids as emulsifier. Food Science and Technology 79: 42-51.

16.Clodoveo M, Dipalmo T, Schiano C, La Notte D (2014) Why does this kind of innovations develop so slowly if, in contrast, the industrial food sector is characterised by a high speed of progress?. Revista de Ingeniería Agrícola. 45: 49-59.

17.Costagli G y Betti M (2015) Avocado oil extraction processes: method for coldpressed high-quality edible oil production versus traditional production. Journal of Agricultural Engineering. XLVI: 115-122.

18. Official Methods and Recommended Practices of the AOCS, 7th Edition, or to purchase individual methods, visit the Methods section of the AOCS website (https://www.aocs.org/attain-labservices/methods). 
19. Rodríguez R, Robaina M, Jáuregui H,
Blanco G, y Rodríguez Ch (2014). Empleo de la radiación ultrasónica para la extracción de compuestos bioactivos provenientes de fuentes naturales. Estado actual y perspectivas. 15: 139-147.

20. Robles $O$ y Osuna $\mathbf{M}$ (2012) Ultrasonido y sus aplicaciones en el procesamiento de alimentos. Revista Iberoamericana de Tecnología Postcosecha. 13:109-122.

21. Cowan K y Wolstenholme N (2016) Avocado. En B. Caballero, P. Finglas, y F. Toldrá. (Eds.), Encyclopedia of Food and Health (pp. 294-300). Oxford, Reino Unido: Academic Press.
22.Tacias $\mathbf{P}$, Rosales $\mathbf{Q}$ y Torrestiana $\mathbf{S}$ (2016) Evaluación y caracterización de grasas y aceites residuales de cocina para la producción de biodiésel: un caso de estudio. Revista Internacional de Contaminación Ambiental, 32: 303-313.

23. Bernal J, Diaz C, Osorio C, Tamayo A, Osorio W, Córdoba O, Londoño $M$, Kondo D, Carabalí A, Varón E, Caicedo A, Tamayo P, Sandoval A, Forero, F, García J y Londoño M (2015) Actualización Tecnológica Buenas Prácticas Agrícolas (BPH) en el cultivo de aguacate. Corpoica.
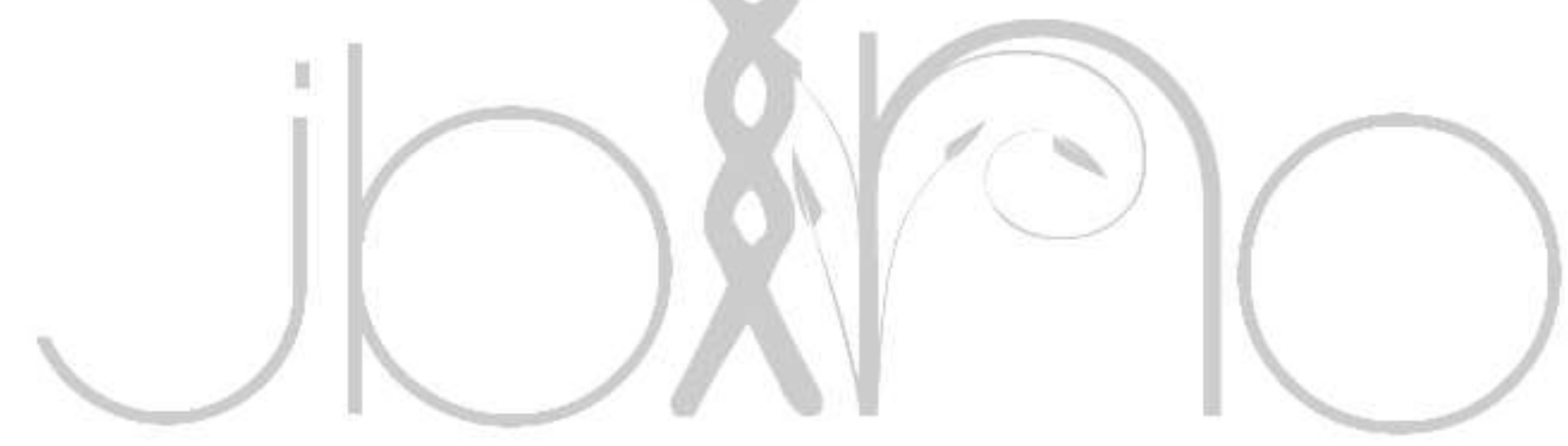